\title{
The impact of eggshell colour and spot area in Japanese quails: II. Slaughter and carcass characteristic
}

\author{
Sema Alasahan', Gulsen Copur Akpinar², Sibel Canogullari³, Mikail Baylan ${ }^{4}$
}

\author{
${ }^{1}$ Mustafa Kemal University, Veterinary Faculty, Department of Animal Science, Hatay, Turkey. \\ ${ }^{2}$ Mustafa Kemal University, Agriculture Faculty, Department of Animal Science, Hatay, Turkey. \\ ${ }^{3}$ Nigde University, Agricultural Sciences and Technologies Faculty, Department of Animal Production and Technologies, Nigde, Turkey. \\ ${ }^{4}$ Cukurova University, Agriculture Faculty, Department of Animal Science, Adana, Turkey.
}

\begin{abstract}
This study was carried out to investigate the effects of eggshell colour and spot properties (colour and size of the spot area) on growth performance and carcass traits of Japanese quail (Coturnix coturnix japonica) eggs. Study material were allocated to five groups according to their eggshell and spot colours: black spots on greyish white coloured eggshell (I), blue spots on greyish white coloured eggshell (II), diffuse brown spots on greyish brown coloured eggshell (III), brown spots on light green colored eggshell (IV), and small brown spots on greyish brown coloured eggshell (V). The size of the spotted area was determined in each egg group using digital image analysis. The groups did not differ for body weight and length of the shank at the end of the growth period. However, the groups differed significantly for carcass yield after slaughter (not eviscerated) and carcass yield. These parameters were highest in Group I (82.08 and 76.09\%) and lowest in Group III (80.20 and 73.86\%). Digital image analysis demonstrated that heart length, cardiac fat area, gizzard width, and intestine length varied between the groups. Cardiac fat area was largest in Group III $\left(0.86 \mathrm{~cm}^{2}\right)$ and smallest in Group V $\left(0.65 \mathrm{~cm}^{2}\right)$. Gizzard width was greatest in Group I $(2.63 \mathrm{~cm})$ and smallest in Group V $(2.47 \mathrm{~cm})$. Intestine length was greatest in Group V $(78.45 \mathrm{~cm})$ and smallest in Group IV $(72.39 \mathrm{~cm})$. Body weight, shank length, and slaughter and carcass weight do not vary in relation to eggshell colour or the size of the spotted area. The lengths of intestine and heart, gizzard width, and cardiac fat area do vary in relation to eggshell colour or the size of the spotted area.
\end{abstract}

Key Words: digital image, growth performance, quail, spot colour

\section{Introduction}

The eggshell provides mechanic protection for the egg content and the developing embryo. It also serves as a barrier against microorganisms and as a source of calcium for the embryo. The eggshell has other important functions such as enabling gas exchange between the egg and the environment by avoiding excessive dehydration, by means of the permeable pores on its surface.

In nature, the colour of the eggshell camouflages the egg. In quail eggs, both the background colour and spot colour of the eggshell vary. The background colour of the eggshell varies from white to light tan and light brown. In quail eggs, the colour of the spots can be blue, black, or brown (Narahari et al., 1988). While the blue-green coloured biliverdin is an antioxidant eggshell pigment, the brown coloured protoporphyrin is a pro-oxidative eggshell

Received April 18, 2016 and accepted May 24, 2016. Corresponding author: gulsenankara@gmail.com

http://dx.doi.org/10.1590/S1806-92902016000900002

Copyright (c) 2016 Sociedade Brasileira de Zootecnia. This is an Open Access article distributed under the terms of the Creative Commons Attribution License (http://creativecommons.org/licenses/by/4.0/), which permits unrestricted use, distribution, and reproduction in any medium, provided the original work is properly cited. pigment (Moreno and Osorno, 2003). In some species, the eggshell colour is associated with the body composition and the immune status (immune competence) of both the female and the progeny (Moreno et al., 2004; Siefferman et al., 2006; Krist and Grim, 2007). It has been reported that the intensity of the blue-green colour of the eggs of the pied flycatcher (Ficedula hypoleuca), apart from being positively correlated with the biliverdin content of the eggshell, is also an indicator of the nutritional status of the laying females (Moreno et al., 2006). Duval et al. (2013) reported that the eggshell of the eggs laid by female quails fed a diet with a restricted antioxidant capacity contained more protoporphyrin and less biliverdin. On the basis of these data, the researchers suggested that the brightness of the eggshell would decrease whilst the colour intensity of the eggshell would increase in eggs laid by female quails fed as such. Several studies have pointed out to a positive correlation between eggshell colour and the health status of the female and/or chick, and parameters of immune capacity such as maternal antibody levels and yolk testosterone and yolk lutein concentrations (Moreno et al., 2005; Hargitai et al., 2008). The pigments held responsible for the formation of reddish spots in spotted eggs, according to the structuralfunction hypothesis, namely, the protoporphyrins, are 
deposited in the parts of the eggshell characterized by less calcium deposition. García-Navas et al. (2011) reported that in eggs of blue tit (Cyanistes caeruleus), the level of the protoporphyrin pigment in the eggshell is partly correlated with eggshell thickness.

The hatching weight of the chick is an important indicator of its future body weight. The egg weight, eggshell weight, eggshell thickness, and egg yolk and egg white weights are significant traits, which have an effect on the egg quality, hatchling weight, and hatching results (Khurshid et al., 2003; Seker et al., 2004). The effect of eggshell colour on the hatching weight of chicks has been investigated in previous research. Hassan et al. (2013) determined that, in quail eggs, four different eggshell colours (light, dotted, spotted, and dark) had a significant effect on the chick weight and the proportion of the chick weight to the egg weight (chick weight/egg weight). It has been reported that eggshell colour, in relation to egg quality, may affect late stage embryonic development as well as chick development from hatching to the start of feed consumption (Farghly et al., 2012). Furthermore, Farghly et al. (2015) determined that the hatching weight differed among chicks that hatched from white, spotted violet, and spotted brown quail eggs.

This study aimed to investigate the impact of eggshell colour and maculation (spot colour and size of spotted area) on chick hatching weight, weekly body weights, and slaughter and carcass traits, and to determine the variance of these traits by sex. The digital image analysis method was used to determine the differences between the study groups for the area and length measurements of some visceral organs (heart, gizzard, and intestine).

\section{Material and Methods}

Hatching eggs, collected within a three-day period from a private holding raising Japanese quails, constituted the material of the study. The eggs underwent macroscopic examination at the laboratory, and broken, cracked, abnormally shaped, and soiled eggs were excluded from the study. The experiment involved 1,062 eggs from 16-wk-old Japanese quail (Coturnix coturnix japonica), which reached 95\% egg production.

Prior to being incubated, the hatching eggs were macroscopically examined and allocated to five groups according to their eggshell and spot colour. Each egg was numbered individually. The size of the spotted eggshell area of each egg included in all groups was determined by digital image analysis (Table 1). A mechanism with a measurement scale was set up for the digital imaging process. The individually numbered eggs were placed in the mechanism and were imaged at an approximate distance of $20 \mathrm{~cm}$. Each egg was photographed from one side, and then turned $180^{\circ}$ to the other side to be photographed again. The size of the spotted area was expressed in $\mathrm{cm}^{2}$.

Prior to incubation, all eggs included in each group were weighed individually to determine egg initial weight. The eggs were randomly placed in the setter with three repeats, such that each tray provided for one repeat. In the setter, the temperature was set at $37.6{ }^{\circ} \mathrm{C}$ and the relative humidity was adjusted to $60-65 \%$. On day 14 of embryonic development, individual compartments were established for each egg included in the same group, and the hatching period was initiated by placing eggs of the same group in an individual compartment. In the hatching machine, the temperature was set at $37.2{ }^{\circ} \mathrm{C}$ and the relative humidity was adjusted to $65-70 \%$.

The chicks, which hatched from the incubated eggs included in each study group, were weighed individually and identified using wing bands. To determine their body weights, the individually identified chicks were transferred to growth cages. During the first two weeks of the growth period, 638 quail chicks were raised. The chicks included in each group were individually weighed on a weekly basis so as to determine and record their weekly body weights. Following the weight measurement performed in the second week, the chicks were sexed. Quails were sexed at three weeks of age, according to the appearance of the breast feathers (feather sexing). Subsequently, $80(4 \times 20$; $4=$ number of repeats, $20=$ number of animal in each

Table 1 - Distribution of eggs according to the trial group $\left(\mathrm{cm}^{2}\right)$

\begin{tabular}{|c|c|c|c|c|}
\hline \multirow{2}{*}{ Group } & \multirow{2}{*}{ Total } & \multicolumn{3}{|c|}{ Spotted area values determined by digital image } \\
\hline & & Spotted area-1 & Spotted area-2 & Total spotted area ${ }^{1}$ \\
\hline Black spots on greyish white coloured eggshell (I) & 213 & $1.74 \pm 0.03 \mathrm{~d}$ & $1.20 \pm 0.05 \mathrm{~d}$ & $2.94 \pm 0.10 \mathrm{~d}$ \\
\hline Blue spots on greyish white coloured eggshell (II) & 215 & $2.90 \pm 0.09 \mathrm{c}$ & $1.98 \pm 0.07 \mathrm{c}$ & $4.87 \pm 0.14 \mathrm{c}$ \\
\hline Diffuse brown spots on greyish brown coloured eggshell (III) & 213 & $4.01 \pm 0.10 \mathrm{a}$ & $3.39 \pm 0.10 \mathrm{a}$ & $7.40 \pm 0.10 \mathrm{a}$ \\
\hline Brown spots on light green coloured eggshell (IV) & 210 & $3.62 \pm 0.10 \mathrm{~b}$ & $2.78 \pm 0.09 b$ & $6.41 \pm 0.17 \mathrm{~b}$ \\
\hline Small brown spots on greyish brown coloured eggshell (V) & 210 & $1.08 \pm 0.05 \mathrm{e}$ & $0.92 \pm 0.04 \mathrm{e}$ & $2.00 \pm 0.09 \mathrm{e}$ \\
\hline
\end{tabular}

${ }^{1}$ Sum of spotted area- 1 and spotted area- 2 .

a-e - means followed by different letters in the same column are statistically different. 
repeat) animals of each sex were assigned to each group. The weekly body weights of 80 chicks from each group, and in total 400 chicks from five groups, were determined. Furthermore, in the 5th week, the shank length of each chick was measured on an individual basis. A digital calliper was used to measure the shank length. Shank length was expressed in $\mathrm{mm}$ as the distance between the proximal and distal ends of the tarsometatarsal bone.

During the five-week growth period, the animals received a diet containing $3000 \mathrm{kcal}$ energy $/ \mathrm{kg}$ and $22 \%$ crude protein.

In the 5 th week, a total of 400 animals $(80 \times 5)$ from five groups were weighed to determine their body weights. The quails with body weights closest to the mean value (either above or below the mean value) were chosen for slaughter. In each group, 200 quails were selected for slaughter $(5 \times 40$; 20 females and 20 males). The selected animals were weighed one more time prior to being slaughtered, and their weights were recorded together with their sex.

Before the abdomen was cut open, the carcass weight after slaughter (not eviscerated) was determined. Subsequently, the abdomen was cut open, and the visceral organs except for the kidneys were removed, aiming to determine the weight of the eviscerated carcass. The carcasses were cut into the breast, wings, right thigh, left thigh and back, and the weights of these cut-up parts were measured. Of the edible visceral organs, the heart, liver, and gizzard (full) were weighed. Of the inedible visceral organs, the full intestine was also weighed.

Following the slaughter of the animals and the cuttingup of their carcasses, of the visceral organs, the heart, gizzard, and intestine were placed into separate storage bags together with the wing number of the animals showing their individual identification number and group. Before being imaged for digital image analysis, the visceral organs were stored in a deep freezer at $-18{ }^{\circ} \mathrm{C}$ for approximately a week. Subsequently, the visceral organs were imaged and their images were stored in a flash memory device. The length, width, and surface area measurements of the visceral organs were performed using 399 of these images with a favourable resolution for digital image analysis.

The definition of the measurement areas of the visceral organs and images of these measurement areas are presented below (McLelland, 1990):

Gizzard area-1 and Gizzard area-2 $\left(\mathrm{cm}^{2}\right)$ : the size of the area of the lateral surfaces (left and right surfaces) of the muscular stomach (gaster); Gizzard length $(\mathrm{cm})$ : the distance between the thin craniodorsal muscle (m. tenuis craniodorsalis) and the thin caudoventral muscle (m. tenuis caudoventralis); Gizzard width $(\mathrm{cm})$ : the distance between the thick caudodorsal muscle (m. crassus caudodorsalis) and the thick cranioventral muscle (m. crassus cranioventralis).

Cardiac fat area $\left(\mathrm{cm}^{2}\right)$ : image of the fat-filled groove visible on the auricular surface of the heart; Heart length $(\mathrm{cm})$ : the distance between the base of the heart (basis cordis) and the apex of the heart (apex cordis); Heart width (cm): the width of the heart at the atrioventricular level.

Intestine length $(\mathrm{cm})$ : total length of the small intestines (duodenum, jejunum, and ileum), the large intestine (colon), and the cloaca.

The SPSS package was used for the statistical analysis of the data obtained in this study. Group data pertaining to the characteristics determined were compared by analysis of variance, and groups that differed were detected by Duncan's multiple comparison test. To determine whether sex had any impact on each of the characteristics investigated, the data was analysed by the two-sample $t$ test to determine the significance of the difference between two mean values.

\section{Results}

Although the hatching weights of the chicks, their body weights in the 3th, 4th, and 5th weeks, and their shank lengths in the 5th week were similar in all of the study groups, the body weights of the chicks in the 1st and 2nd weeks differed significantly between the study groups $(\mathrm{P}<0.001)$ (Table 2).

In all of the study groups, the body weights of the female quails in the 5 th week were greater than those of the males (Table 3), and this difference between the sexes was statistically significant $(\mathrm{P}<0.05, \mathrm{P}<0.01, \mathrm{P}<0.001)$. Furthermore, statistically significant differences were also determined between the male and female quails in Groups I (2.94), IV (6.41), and V (2.00) for shank length in the 5th week $(\mathrm{P} \leq 0.05, \mathrm{P}<0.001)$.

The differences observed between the study groups for the wing and left thigh weights (Table 4) were statistically significant $(\mathrm{P}<0.01)$. Carcass yield after slaughter (not eviscerated) $(\mathrm{P}<0.05)$, carcass yield $(\mathrm{P}<0.01)$, breast yield $(\mathrm{P}<0.01)$, wing yield $(\mathrm{P}<0.01)$, left thigh yield $(\mathrm{P}<0.01)$, and gizzard yield $(\mathrm{P}<0.05)$ varied between the study groups.

In all of the study groups, the slaughter weights $(\mathrm{g})$ of the female quails were greater than those of the males $(\mathrm{P}<0.001)$, whilst the carcass yields $(\%)$ of the males were higher than those of the females $(\mathrm{P}<0.05, \mathrm{P}<0.01, \mathrm{P}<0.001)$ (Table 5). Furthermore, in all of the study groups, the weights of the liver, gizzard, and intestine were greater in the female animals when compared with males, and this 
Table 2 - Body weight and shank length of the study groups ( \pm standard error of the mean)

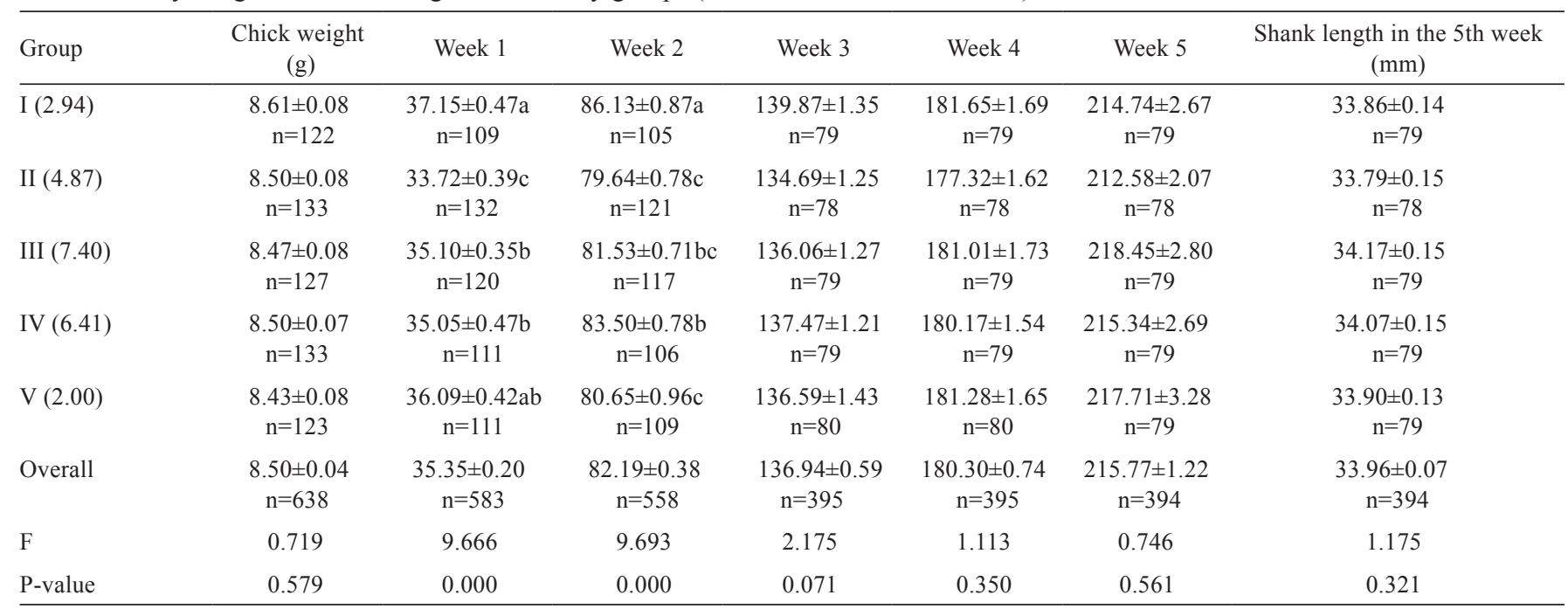

a-c - differences between mean values with different letters in the same column are statistically significant $(\mathrm{P}<0.001)$.

F - ANOVA; P-value - significance level $(\alpha=0.05)$.

Table 3 - Body weights of animals included in each study group with respect to sex

\begin{tabular}{|c|c|c|c|c|c|}
\hline Group & Sex & Week 3 (g) & Week $4(\mathrm{~g})$ & Week $5(\mathrm{~g})$ & Shank length in the 5 th week $(\mathrm{mm})$ \\
\hline I (2.94) & $\begin{array}{c}\text { Female } \\
\text { Male } \\
t \\
\text { P-value }\end{array}$ & $\begin{array}{c}139.48 \pm 1.85 \\
140.23 \pm 1.99 \\
-0.276 \\
0.784\end{array}$ & $\begin{array}{c}181.33 \pm 2.49 \\
181.95 \pm 2.34 \\
-0.179 \\
0.858\end{array}$ & $\begin{array}{c}227.94 \pm 3.37 \\
202.51 \pm 3.06 \\
5.603 \\
0.000\end{array}$ & $\begin{array}{c}34.15 \pm 0.20 \\
33.59 \pm 0.20 \\
1.973 \\
0.052\end{array}$ \\
\hline II (4.87) & $\begin{array}{c}\text { Female } \\
\text { Male } \\
\mathrm{t} \\
\text { P-value }\end{array}$ & $\begin{array}{c}134.00 \pm 1.92 \\
135.52 \pm 1.50 \\
-0.604 \\
0.548\end{array}$ & $\begin{array}{c}177.10 \pm 2.46 \\
177.59 \pm 2.02 \\
-0.150 \\
0.881\end{array}$ & $\begin{array}{c}217.71 \pm 3.18 \\
207.71 \pm 2.49 \\
2.489 \\
0.015\end{array}$ & $\begin{array}{c}33.94 \pm 0.24 \\
33.66 \pm 0.18 \\
0.934 \\
0.353\end{array}$ \\
\hline III (7.40) & $\begin{array}{c}\text { Female } \\
\text { Male } \\
t \\
\text { P-value }\end{array}$ & $\begin{array}{c}138.80 \pm 1.84 \\
133.38 \pm 1.66 \\
2.187 \\
0.032\end{array}$ & $\begin{array}{c}185.98 \pm 2.49 \\
176.18 \pm 2.17 \\
2.976 \\
0.004\end{array}$ & $\begin{array}{c}233.43 \pm 2.98 \\
204.56 \pm 3.43 \\
6.313 \\
0.000\end{array}$ & $\begin{array}{c}34.25 \pm 0.25 \\
34.10 \pm 0.17 \\
0.486 \\
0.628\end{array}$ \\
\hline IV $(6.41)$ & $\begin{array}{c}\text { Female } \\
\text { Male } \\
\mathrm{t} \\
\text { P-value }\end{array}$ & $\begin{array}{c}133.38 \pm 1.66 \\
139.07 \pm 1.72 \\
1.274 \\
0.207\end{array}$ & $\begin{array}{c}184.32 \pm 1.99 \\
176.32 \pm 2.17 \\
2.706 \\
0.008\end{array}$ & $\begin{array}{c}229.28 \pm 2.97 \\
202.42 \pm 3.31 \\
6.011 \\
0.000\end{array}$ & $\begin{array}{c}34.63 \pm 0.19 \\
33.56 \pm 0.20 \\
3.904 \\
0.000\end{array}$ \\
\hline
\end{tabular}

$\mathrm{t}$ - independent samples (t test); P-value - significance level $(\alpha=0.05)$.

difference between the sexes was statistically significant $(\mathrm{P}<0.001)$ (Table 6).

The study groups differed significantly for heart length $(\mathrm{P}<0.001)$, cardiac fat area $(\mathrm{P}<0.01)$, gizzard width $(\mathrm{P}<0.01)$, and intestine length $(\mathrm{P}<0.01)$ (Figures 1, 2, and 3) (Table 7). The heart length and gizzard width were highest in Group I (2.94), the cardiac fat area was largest in Group III (7.40), and the intestine length was greatest in Group V (2.00).

\section{Discussion}

The mean hatchling weight calculated for all of the study groups was $8.50 \mathrm{~g}$. The hatching weight of the chicks was highest in Group I (8.61 g) and lowest in Group V (8.43 g). The chick weights determined for the quail chicks in the present study were lower than the hatchling weight (10.02 g) reported by Obregón et al. (2012) and higher than the hatching weight (7.80 g) reported by Caglayan and Seker (2013) for quail 
Table 4 - Slaughter and carcass characteristics of the study groups

\begin{tabular}{|c|c|c|c|c|c|c|c|c|}
\hline Characteristic & $\begin{array}{c}\text { I }(2.94) \\
n=39\end{array}$ & $\begin{array}{c}\text { II }(4.87) \\
n=39\end{array}$ & $\begin{array}{c}\text { III (7.40) } \\
n=40\end{array}$ & $\begin{array}{c}\text { IV }(6.41) \\
n=39\end{array}$ & $\begin{array}{c}\mathrm{V}(2.00) \\
\mathrm{n}=39\end{array}$ & $\mathrm{~F}$ & P-value & $\begin{array}{c}\text { Total } \\
n=197\end{array}$ \\
\hline Slaughter weight (g) & $213.69 \pm 2.53$ & $210.41 \pm 1.57$ & $218.10 \pm 2.88$ & $213.17 \pm 2.37$ & $215.04 \pm 2.25$ & 1.414 & 0.231 & $214.11 \pm 1.06$ \\
\hline WCAS (g) & $175.24 \pm 1.88$ & $171.52 \pm 1.32$ & $174.73 \pm 2.34$ & $170.07 \pm 1.76$ & $172.98 \pm 1.46$ & 1.454 & 0.218 & $172.92 \pm 0.80$ \\
\hline Carcass weight $^{1}(\mathrm{~g})$ & $162.40 \pm 1.65$ & $159.11 \pm 1.18$ & $160.85 \pm 1.99$ & $157.12 \pm 1.61$ & $160.16 \pm 1.33$ & 1.544 & 0.191 & $159.93 \pm 071$ \\
\hline Breast weight (g) & $58.84 \pm 0.85$ & $57.12 \pm 0.84$ & $58.73 \pm 2.48$ & $57.53 \pm 0.76$ & $56.12 \pm 0.63$ & 0.761 & 0.552 & $57.66 \pm 0.59$ \\
\hline Wing weight (g) & $13.61 \pm 0.20 \mathrm{~b}$ & $13.59 \pm 0.18 b$ & $15.53 \pm 0.93 \mathrm{a}$ & $13.53 \pm 0.18 b$ & $15.08 \pm 0.26 \mathrm{a}$ & 4.332 & 0.002 & $14.28 \pm 0.21$ \\
\hline Right thigh weight (g) & $29.87 \pm 0.37$ & $29.27 \pm 0.38$ & $29.25 \pm 0.56$ & $28.38 \pm 0.51$ & $29.25 \pm 0.32$ & 1.458 & 0.217 & $29.21 \pm 0.20$ \\
\hline Left thigh weight (g) & $29.50 \pm 0.40 \mathrm{a}$ & $28.67 \pm 0.27 \mathrm{ab}$ & $28.31 \pm 0.42 \mathrm{cb}$ & $27.63 \pm 0.30 \mathrm{c}$ & $28.72 \pm 0.32 \mathrm{ab}$ & 3.814 & 0.005 & $28.56 \pm 0.16$ \\
\hline Back and neck weight (g) & $30.67 \pm 0.42$ & $29.87 \pm 0.43$ & $30.52 \pm 0.51$ & $29.81 \pm 0.49$ & $30.74 \pm 0.39$ & 0.977 & 0.421 & $30.32 \pm 0.20$ \\
\hline Heart weight $(\mathrm{g})$ & $2.06 \pm 0.05$ & $2.00 \pm 0.04$ & $2.77 \pm 0.61$ & $2.04 \pm 0.05$ & $2.00 \pm 0.05$ & 1.430 & 0.225 & $2.18 \pm 0.13$ \\
\hline Liver weight (g) & $5.96 \pm 0.28$ & $5.66 \pm 0.22$ & $6.15 \pm 0.29$ & $5.75 \pm 0.24$ & $5.89 \pm 0.19$ & 0.574 & 0.681 & $5.88 \pm 0.11$ \\
\hline Gizzard weight (g) & $4.82 \pm 0.12$ & $4.75 \pm 0.12$ & $4.95 \pm 0.13$ & $5.15 \pm 0.14$ & $4.92 \pm 0.12$ & 1.453 & 0.218 & $4.92 \pm 0.06$ \\
\hline Intestine weight (g) & $9.43 \pm 0.32$ & $9.12 \pm 0.24$ & $8.92 \pm 0.33$ & $9.32 \pm 0.32$ & $9.24 \pm 0.25$ & 0.506 & 0.731 & $9.21 \pm 0.13$ \\
\hline CYAS (\%) & $82.08 \pm 0.37 \mathrm{a}$ & $81.54 \pm 0.40 \mathrm{ab}$ & $80.20 \pm 0.60 b c$ & $79.87 \pm 0.51 \mathrm{c}$ & $80.60 \pm 0.63 \mathrm{abc}$ & 3.241 & 0.013 & $80.85 \pm 0.23$ \\
\hline Carcass yield² (\%) & $76.09 \pm 0.38 \mathrm{a}$ & $75.67 \pm 0.44 \mathrm{a}$ & $73.86 \pm 0.50 \mathrm{~b}$ & $73.81 \pm 0.54 b$ & $74.64 \pm 061 \mathrm{ab}$ & 4.232 & 0.003 & $74.81 \pm 0.23$ \\
\hline Breast yield (\%) & $33.56 \pm 0.25 a$ & $33.30 \pm 0.40 \mathrm{ab}$ & $32.22 \pm 0.39 \mathrm{c}$ & $33.83 \pm 0.29 \mathrm{a}$ & $32.43 \pm 0.20 \mathrm{bc}$ & 5.030 & 0.001 & $33.06 \pm 0.15$ \\
\hline Wing yield (\%) & $7.78 \pm 0.10 \mathrm{~b}$ & $7.94 \pm 0.12 b$ & $8.85 \pm 0.43 \mathrm{a}$ & $7.98 \pm 0.12 b$ & $8.72 \pm 0.13 \mathrm{a}$ & 4.922 & 0.001 & $8.26 \pm 0.10$ \\
\hline Right thigh yield (\%) & $17.06 \pm 0.14$ & $17.06 \pm 0.15$ & $16.77 \pm 0.26$ & $16.66 \pm 0.19$ & $16.91 \pm 0.13$ & 0.953 & 0.435 & $16.89 \pm 0.08$ \\
\hline Left thigh yield (\%) & $16.84 \pm 0.15 \mathrm{a}$ & $16.72 \pm 0.14 \mathrm{a}$ & $16.21 \pm 0.14 b$ & $16.26 \pm 0.10 b$ & $16.61 \pm 0.13 \mathrm{ab}$ & 4.352 & 0.002 & $16.53 \pm 0.06$ \\
\hline Back and neck yield (\%) & $17.52 \pm 0.29$ & $17.41 \pm 0.21$ & $17.48 \pm 0.19$ & $17.53 \pm 0.22$ & $17.78 \pm 0.20$ & 0.475 & 0.754 & $17.54 \pm 0.09$ \\
\hline Heart yield $(\%)$ & $1.18 \pm 0.03$ & $1.17 \pm 0.02$ & $1.54 \pm 0.30$ & $1.20 \pm 0.02$ & $1.16 \pm 0.03$ & 1.473 & 0.212 & $1.25 \pm 0.06$ \\
\hline Liver yield (\%) & $3.38 \pm 0.14$ & $3.29 \pm 0.12$ & $3.50 \pm 0.15$ & $3.37 \pm 0.13$ & $3.40 \pm 0.11$ & 0.344 & 0.848 & $3.39 \pm 0.06$ \\
\hline Gizzard yield (\%) & $2.75 \pm 0.07 b$ & $2.77 \pm 0.07 b$ & $2.84 \pm 0.06 b$ & $3.03 \pm 0.08 \mathrm{a}$ & $2.84 \pm 0.06 \mathrm{~b}$ & 2.781 & 0.028 & $2.85 \pm 0.03$ \\
\hline
\end{tabular}

a-c - differences between mean values with different letters in the same row are statistically significant $(\mathrm{P}<0.001)$.

F - ANOVA, P-value - significance level $(\alpha=0.05)$.

WCAS - carcass weight after slaughter (not eviscerated); CYAS - carcass yield after slaughter (not eviscerated).

${ }_{1}^{1}$ Excluding the weight of all visceral organs, except for the kidneys.

${ }^{2}$ Calculated on the basis of the carcass weight.
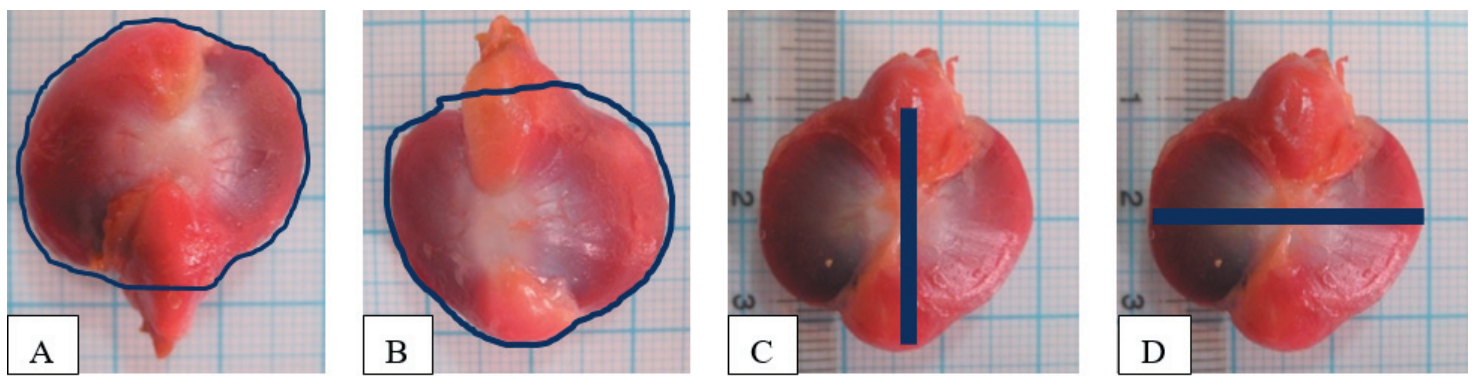

A - left lateral surface-1; B - right lateral surface-2; C - length; D - width.

Figure 1 - Gizzard measurements.
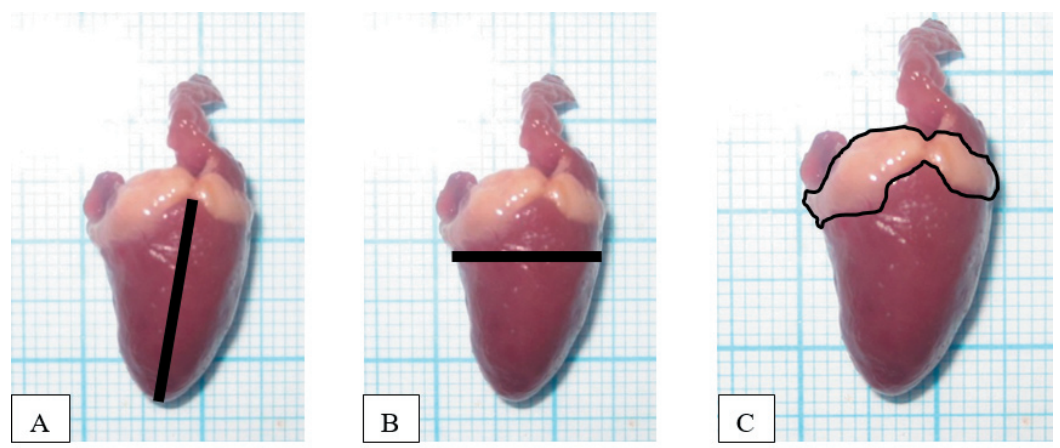

A - length; B - width; C - cardiac fat area.

Figure 2 - Heart measurements. 
chicks. The mean hatching weight calculated for all of the study groups was similar to the mean hatching weights reported by Nowaczewski et al. (2010) (8.4 g) and Seker et al. (2004) (8.10 g).

The body weight of the female quails measured in the 5 th week being greater than that of the males was in agreement with previous reports made for Japanese quails by Yalcin et al. (1996), Aytac and Karabayir (2012), and Caglayan and Seker (2015). In the 5th week, the highest body weight for the female quails was $233.43 \mathrm{~g}$ in Group III, whilst the highest body weight for the male quails was $208.79 \mathrm{~g}$ in Group V. These values were higher than the

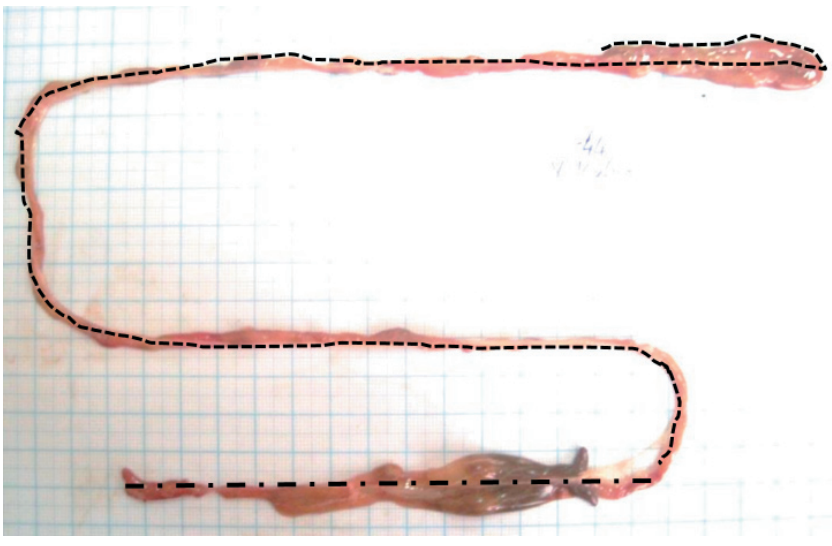

Figure 3 - Measurement of the total length of the intestines.
$198.06 \mathrm{~g}$ for females and $163.28 \mathrm{~g}$ for males reported by Alkan et al. (2010) and $139.56 \mathrm{~g}$ for females and $137.54 \mathrm{~g}$ for males by Karadavut and Taşkın (2014).

In the present study, the mean shank length was 33.96 $\mathrm{mm}$. This value was reported as $3.7 \mathrm{~cm}$ for five-week-old animals by Wilkanowska et al. (2013) and as $3.93 \mathrm{~cm}$ for six-week-old animals by Momoh et al. (2014). The results of the present study demonstrated that the shank length of five-week-old quail chicks ranged between 33.94-34.63 mm in females and between $33.44-34.10 \mathrm{~mm}$ in males. The shank lengths measured in the 5 th week in the present study were higher than the shank lengths reported by Caglayan and Seker (2015) for females $(28.38 \mathrm{~mm})$ and males $(27.78 \mathrm{~mm})$.

The slaughter weights of the animals in Groups I, II, III, IV, and V $(213.69,210.41,218.10,213.17$, and $215.04 \mathrm{~g}$, respectively) were higher than the slaughter weights of Japanese quails measured by Bonos et al. (2010), Hassan et al. (2015), and Caglayan and Seker (2013) as $154.6 \mathrm{~g}$, $168.29 \mathrm{~g}$, and $116.53 \mathrm{~g}$, respectively. While the slaughter weights measured in all of the study groups in the present study were similar to the slaughter weight (213.58 g) reported by Obregón et al. (2012), the carcass weight determined in the present study $(159.93 \mathrm{~g})$ was higher than that reported by the same researchers $(128.97 \mathrm{~g})$. The carcass yields determined in Group I (76.09\%) and Group II (75.67\%) were similar to the carcass yield previously reported by Bonos et al. (2010) (76.37\%). The carcass yields determined

Table 5 - Slaughter and carcass characteristics of the study groups with respect to sex

\begin{tabular}{|c|c|c|c|c|c|c|c|c|c|}
\hline Group & Sex & $\mathrm{n}$ & $\begin{array}{l}\text { Slaughter } \\
\text { weight }(\mathrm{g})\end{array}$ & $\begin{array}{l}\text { WCAS } \\
(\mathrm{g})\end{array}$ & $\begin{array}{c}\text { Carcass weight }{ }^{1} \\
(\mathrm{~g})\end{array}$ & $\begin{array}{l}\text { CYAS } \\
(\%)\end{array}$ & $\begin{array}{c}\text { Carcass yield }{ }^{2} \\
(\%)\end{array}$ & $\begin{array}{c}\text { Breast weight } \\
(\mathrm{g})\end{array}$ & $\begin{array}{c}\text { Back and neck } \\
\text { weight }(\mathrm{g})\end{array}$ \\
\hline \multirow[t]{4}{*}{ I (2.94) } & Female & 20 & $225.64 \pm 2.60$ & $183.80 \pm 1.90$ & $169.52 \pm 1.82$ & $81.53 \pm 0.60$ & $75.19 \pm 0.57$ & $62.28 \pm 1.05$ & $31.43 \pm 0.49$ \\
\hline & Male & 19 & $201.12 \pm 1.78$ & $166.21 \pm 1.58$ & $154.90 \pm 1.43$ & $82.65 \pm 0.39$ & $77.04 \pm 0.41$ & $55.23 \pm 0.69$ & $29.87 \pm 0.67$ \\
\hline & & $\mathrm{t}$ & 7.709 & 7.104 & 6.282 & -1.559 & -2.595 & 5.539 & 1.907 \\
\hline & & P-value & 0.000 & 0.000 & 0.000 & 0.127 & 0.013 & 0.000 & 0.064 \\
\hline \multirow[t]{4}{*}{ II (4.87) } & Female & 19 & $217.41 \pm 1.93$ & $175.37 \pm 1.91$ & $161.57 \pm 1.85$ & $80.69 \pm 0.67$ & $74.34 \pm 0.70$ & $58.77 \pm 0.88$ & $30.70 \pm 0.65$ \\
\hline & Male & 20 & $203.77 \pm 1.21$ & $1.67 .86 \pm 1.42$ & $156.77 \pm 1.34$ & $82.37 \pm 0.38$ & $76.92 \pm 0.38$ & $55.56 \pm 1.32$ & $29.08 \pm 0.54$ \\
\hline & & $\mathrm{t}$ & 6.054 & 3.174 & 2.121 & -2.211 & -3.288 & 1.995 & 1.925 \\
\hline & & P-value & 0.000 & 0.003 & 0.041 & 0.033 & 0.002 & 0.053 & 0.062 \\
\hline \multirow[t]{4}{*}{ III (7.40) } & Female & 20 & $233.23 \pm 2.38$ & $182.50 \pm 3.16$ & $167.95 \pm 2.87$ & $78.18 \pm 0.82$ & $71.95 \pm 0.73$ & $59.34 \pm 1.22$ & $31.85 \pm 0.82$ \\
\hline & Male & 20 & $202.98 \pm 2.10$ & $166.94 \pm 2.45$ & $153.75 \pm 1.65$ & $82.21 \pm 0.60$ & $75.76 \pm 0.32$ & $53.13 \pm 1.03$ & $29.19 \pm 0.45$ \\
\hline & & $\mathrm{t}$ & 9.534 & 3.889 & 4.291 & -3.968 & -4.759 & 3.873 & 2.839 \\
\hline & & P-value & 0.000 & 0.000 & 0.000 & 0.000 & 0.000 & 0.000 & 0.007 \\
\hline \multirow[t]{4}{*}{ IV (6.41) } & Female & 19 & $226.24 \pm 1.66$ & $177.75 \pm 2.39$ & $163.45 \pm 2.40$ & $78.56 \pm 0.84$ & $72.23 \pm 0.84$ & $59.41 \pm 1.14$ & $31.30 \pm 0.71$ \\
\hline & Male & 20 & $200.76 \pm 1.68$ & $162.76 \pm 1.11$ & $151.11 \pm 1.05$ & $81.11 \pm 0.45$ & $75.32 \pm 0.52$ & $55.74 \pm 0.85$ & $28.38 \pm 0.53$ \\
\hline & & $\mathrm{t}$ & 10.799 & 5.790 & 4.806 & -2.717 & -3.162 & 2.602 & 3.323 \\
\hline & & P-value & 0.000 & 0.000 & 0.000 & 0.010 & 0.003 & 0.013 & 0.002 \\
\hline \multirow[t]{4}{*}{$\mathrm{V}(2.00)$} & Female & 19 & $227.67 \pm 1.93$ & $178.92 \pm 2.01$ & $165.15 \pm 1.86$ & $78.69 \pm 1.10$ & $72.64 \pm 1.03$ & $58.32 \pm 0.96$ & $30.98 \pm 0.65$ \\
\hline & Male & 21 & $203.62 \pm 1.42$ & $167.60 \pm 1.26$ & $155.65 \pm 1.26$ & $82.32 \pm 0.41$ & $76.46 \pm 0.44$ & $54.12 \pm 0.54$ & $30.52 \pm 0.47$ \\
\hline & & $\mathrm{t}$ & 10.187 & 4.869 & 4.282 & -3.215 & -3.525 & 3.899 & 0.588 \\
\hline & & P-value & 0.000 & 0.000 & 0.000 & 0.003 & 0.001 & 0.000 & 0.560 \\
\hline
\end{tabular}

WCAS - carcass weight after slaughter (not eviscerated); CYAS - carcass yield after slaughter (not eviscerated); $\mathrm{t}$ - independent samples $(\mathrm{t}$ test); P-value - significance level $(\alpha=0.05)$.

${ }^{1}$ Excluding the weight of all visceral organs except for the kidneys.

${ }^{2}$ Calculated on the basis of the carcass weight. 
Table 6 - Slaughter and carcass characteristics of the study groups with respect to sex

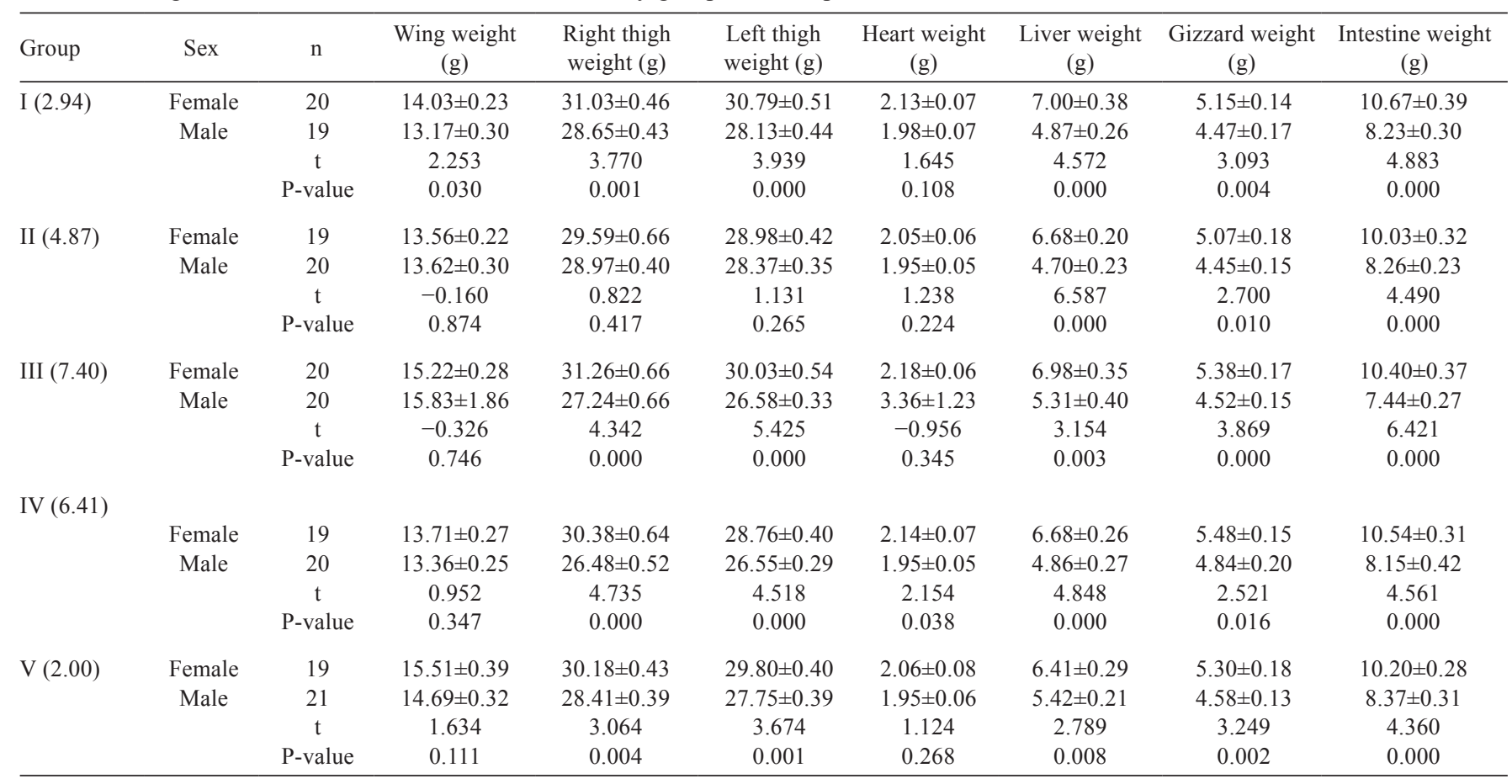

$\mathrm{t}$ - independent samples ( $\mathrm{t}$ test); P-value - significance level $(\alpha=0.05)$.

Table 7 - Digital image analysis measurements of the length, width, and surface area of some visceral organs for the different study groups

\begin{tabular}{|c|c|c|c|c|c|c|c|c|}
\hline Characteristic & $\mathrm{n}$ & I (2.94) & III (7.40) & IV $(6.41)$ & $\mathrm{V}(2.00)$ & $\mathrm{F}$ & P-value & Overall \\
\hline Heart length $(\mathrm{cm})$ & 39 & $1.91 \pm 0.03 \mathrm{a}$ & $1.73 \pm 0.03 b$ & $1.69 \pm 0.04 \mathrm{~b}$ & $1.77 \pm 0.05 b$ & 8.153 & 0.000 & $1.78 \pm 0.02$ \\
\hline Heart width $(\mathrm{cm})$ & 40 & $1.47 \pm 0.02$ & $1.43 \pm 0.02$ & $1.44 \pm 0.02$ & $1.43 \pm 0.03$ & 1.243 & 0.297 & $1.44 \pm 0.01$ \\
\hline Heart surface area $\left(\mathrm{cm}^{2}\right)$ & 29 & $2.75 \pm 0.05$ & $2.74 \pm 0.04$ & $2.67 \pm 0.05$ & $2.69 \pm 0.09$ & 0.528 & 0.664 & $2.72 \pm 0.03$ \\
\hline Cardiac fat area $\left(\mathrm{cm}^{2}\right)$ & 19 & $0.74 \pm 0.04 b c$ & $0.86 \pm 0.03 \mathrm{a}$ & $0.82 \pm 0.03 \mathrm{ab}$ & $0.65 \pm 0.06 \mathrm{c}$ & 4.725 & 0.004 & $0.78 \pm 0.02$ \\
\hline Gizzard length (cm) & 39 & $2.89 \pm 0.32$ & $2.84 \pm 0.04$ & $2.76 \pm 0.05$ & $2.87 \pm 0.05$ & 1.494 & 0.220 & $2.84 \pm 0.02$ \\
\hline Gizzard width (cm) & 40 & $2.63 \pm 0.03 a$ & $2.55 \pm 0.03 \mathrm{ab}$ & $2.49 \pm 0.04 b$ & $2.47 \pm 0.05 b$ & 4.377 & 0.006 & $2.55 \pm 0.02$ \\
\hline Gizzard area-1 $\left(\mathrm{cm}^{2}\right)$ & 29 & $5.60 \pm 0.10$ & $5.34 \pm 0.09$ & $5.21 \pm 0.12$ & $5.40 \pm 0.14$ & 2.375 & 0.073 & $5.40 \pm 0.06$ \\
\hline Gizzard area-2 $\left(\mathrm{cm}^{2}\right)$ & 21 & $5.65 \pm 0.09$ & $5.38 \pm 0.09$ & $5.27 \pm 0.11$ & $5.43 \pm 0.16$ & 2.531 & 0.060 & $5.44 \pm 0.05$ \\
\hline Intestine length $(\mathrm{cm})$ & & $\begin{array}{c}74.09 \pm 1.04 b \\
n=39\end{array}$ & $\begin{array}{c}73.90 \pm 1.14 b \\
n=40\end{array}$ & $\begin{array}{c}72.39 \pm 1.47 b \\
n=29\end{array}$ & $\begin{array}{c}78.45 \pm 1.25 a \\
n=35\end{array}$ & 4.397 & 0.005 & $\begin{array}{c}74.76 \pm 0.12 \\
n=143\end{array}$ \\
\hline
\end{tabular}

a-c - differences between mean values with different letters in the same row are statistically significant $(\mathrm{P}<0.001)$.

F - ANOVA; P-value - significance level $(\alpha=0.05)$.

in all of the study groups in the present study were higher than the carcass yields reported by Obregón et al. (2012) (61.14\%) and Caglayan and Seker (2013) (58.65\%).

In the present study, the slaughter weights being greater in female quails in comparison with males in all of the study groups was in agreement with the results of several literature reports (Alkan et al., 2010; Bonos et al., 2010; Aytac and Karabayir, 2012; Kosshak et al., 2014; Ojedapo and Amao, 2014; Hassan et al., 2015; Karadavut and Taşkın, 2014; Caglayan and Seker, 2015), but differed from the report of Caglayan and Seker (2013). Furthermore, the carcass yields of the males being higher than those of the females in all of the study groups was in agreement with the results reported by Alkan et al. (2010), Kosshak et al. (2014), and Hassan et al. (2015).

The mean values determined in the present study for the heart weight and cardiac fat area $\left(2.18 \mathrm{~g}\right.$ and $\left.0.78 \mathrm{~cm}^{2}\right)$ were higher than the values reported by Caglayan and Seker (2013) (0.99 g) and Hassan et al. (2015) (1.5 g) and lower than the value reported by Guluwa et al. (2014) (4.05 g).

Average gizzard length and gizzard width (2.84 and $2.55 \mathrm{~cm}$ ) were higher than those determined by Omonona et al. (2014) as 2.10 and $1.83 \mathrm{~cm}$, respectively.

In the present study, the mean intestine length and intestine weight values calculated for all of the study groups were $74.76 \mathrm{~cm}$ and $9.21 \mathrm{~g}$, respectively. While the 
mean intestine length determined in this study was similar to that reported by Wilkanowska et al. (2013) for five-weekold Japanese quails $(73.3 \mathrm{~cm})$, this value was higher than that reported by Hassan et al. (2015) for six-week-old animals $(54.86 \mathrm{~cm})$. Furthermore, the total length $(63.44 \mathrm{~cm})$ of the small $(55.6 \mathrm{~cm})$ and large $(7.84 \mathrm{~cm})$ intestines and the intestine weight (5.35 g) reported by Hena et al. (2012); the total length $(56.41)$ of the small $(50.02 \mathrm{~cm})$ and large $(6.39 \mathrm{~cm})$ intestines and the intestine weight $(3.86 \mathrm{~g})$ reported by Guluwa et al. (2014); and the total intestine length $(61.93 \mathrm{~cm})$ and intestine weight $(7.69 \mathrm{~g})$ reported by Samadi and Sahneh (2015) were lower than the results obtained in the present study.

\section{Conclusions}

Body weight, shank length, and slaughter and carcass weight do not vary in relation to eggshell colour or the size of the spotted area. The eggshell colour or the size of the spotted area affect wing weight, left thigh weight, yield of the carcass after slaughter (not eviscerated), carcass yield, breast yield, wing yield, and gizzard yield. The lengths of intestine and heart, gizzard width, and cardiac fat area vary in relation to eggshell colour or the size of the spotted area.

\section{Acknowledgments}

The present study was supported by the Scientific Research Project Unit of Mustafa Kemal University, Turkey (Project no. 1206 M 0117).

\section{References}

Alkan, S.; Karabağ, K.; Galiç, A.; Karslı, T. and Balcığlu, M. S. 2010. Determination of body weight and some carcass traits in Japanese quails (Coturnix coturnix japonica) of different lines. Journal of the Faculty of Veterinary Medicine, Kafkas University $16: 277-280$

Aytac, S. and Karabayir, A. 2012. The effect of floor differences in cages on the incubation results and live weight of Japanese quails. Journal of Animal and Veterinary Advances 11:1204-1207.

Bonos, E. M.; Christaki, E. V. and Florou-Paner, P.C. 2010.Performance and carcass characteristics of Japanese quail as affected by sex or mannan oligosaccharides and calcium propionate. South African Journal of Animal Science 40:173-184.

Caglayan, T. and Seker, E. 2013. Effect of Mentha caucasica on growth performance and carcass characteristics of Japanese quail (Coturnix coturnix japonica). Journal of Animal and Veterinary Advances 12:909-913.

Caglayan, T. and Seker, E. 2015. Dağ nanesinin (Mentha caucasica) japon bildırcinlarının (Coturnix coturnix japonica) performans, bazı vücut ölçüleri ve canlı ağırlık arasındaki ilişkilerine etkisi. Eurasian Journal of Veterinary Sciences 31:33-42.

Duval, C.; Cassey, P.; Mikšík, I.; Reynolds, S. J. and Spencer, K. A. 2013. Condition-dependent strategies of eggshell pigmentation: an experimental study of Japanese quail (Coturnix coturnix japonica). The Journal of Experimental Biology 216:700-708.

Farghly, M. F. A. 2012. Effect of light pulses during incubation on hatch performance in different eggs size of Japanese quail. In: Proceedings of the 3rd Mediterranean Poultry Summit of WPSA and The International Poultry Conference, Alexandria, Egypt.

Farghly, M. F. A.; Mahrose, Kh. M. A. and Abou-Kassem, D. E. 2015. Pre and post hatch performance of different Japanese quail egg colors incubated under photostimulation. Asian Journal of Poultry Science 9:19-30.

García-Navas, V.; Sanz, J. J.; Merino, S.; Martínez-de la Puente, J.; Lobato, E.; del Cerro, S.; Rivero, J.; Ruiz de Castañeda, R. and Moreno, J. 2011. Experimental evidence for the role of calcium in eggshell pigmentation pattern and breeding performance in Blue Tits Cyanistes caeruleus. Journal of Ornithology 152:71-82.

Guluwa, L. Y.; Madaki, Y. A.; Machido, H.; Dantayi, R. J. and Kulokom, S. 2014. Growth performance and carcass evaluation of quails fed graded levels of water soaked sweet orange peel meal (SOPM). Advances in Life Science and Technology 20:2224-7181.

Hargitai, R.; Herényi, M. and Török, J. 2008. Eggshell coloration in relation to male ornamentation, female condition and egg quality in the collared flycatcher Ficedula albicollis. Journal Avian Biology 39:413-422.

Hassan, H. A.; El-Nesr, S. S.; Osman A. M. R. and Arram G. A. 2013. Ultrastructure of eggshell, egg weight loss and hatching traits of Japanese quail varying in eggshell color and pattern using image analysis. Egyptian Poultry Science Journal 34:1-17.

Hassan, K. H.; Abd-Alsattar, A. R.; Yassen, H. A. A.; Abed, H. T. and Abdul Wahab, D. A. A. 2015. Effect of variety, age and sex in some productive traits in Japanese quail in Iraq. American Journal of Bio Science 3:55-58

Hena, S. A.; Sonfada, M. L.; Danmaigoro, A.; Bello, A. and Umar, A. A. 2012. Some comparative gross and morphometrical studies on the gastrointestinal tract in pigeon (columbia livia) and Japanese quail (coturnix japonica). Scientific Journal of Veterinary Advances 1:57-64.

Karadavut, U. and Taşkın, A. 2014. Estimation of heritability of weight gain of Japanese quail by using analysis of variance, maximum and restricted Likelihood tests. Turkish Journal of Agricultural and Natural Sciences 1:59-63.

Khurshid, A.; Farooq, M.; Durrani, F. R.; Sarbiland, K. and Chand, N. 2003. Predicting egg weight, shell weight, shell thickness and hatching chick weight of Japanese quails using various egg traits as regressors. International Journal Poultry Science 2:164-167.

Kosshak, A. S.; Dim, N. I.; Momoh, O. M. and Gambo, D. 2014. Effect of sex on carcass characteristics and correlation of body weight and blood component in Japanese quails. IOSR Journal of Agriculture and Veterinary Science 7:72-76.

Krist, M. and Grim, T. 2007. Are blue eggs a sexually selected signal of female collared flycatchers? A cross-fostering experiment. Behavioral Ecology and Sociobiology 61:863-876.

McLelland, J. 1990. A colour atlas of avian anatomy. BPCC Hazell Books Ltd, Aylesbury, England.

Momoh, O. M.; Gambo, D. and Dim, N. I. 2014. Genetic parameters of growth, body, and egg traits in Japanese quails (Cotournix cotournix japonica) reared in southern guinea savannah of Nigeria. Journal of Applied Biosciences 79:6947-6954.

Moreno, J. and Osorno, J. L. 2003. Avian egg colour and sexual selection: does eggshell pigmentation reflect female condition and genetic quality? Ecology Letters 6:803-806.

Moreno, J.; Osorno, J. L.; Morales, J.; Merino, S. and Tomás, G. 2004. Egg colouration and male parental effort in the Pied Flycatcher Ficedula Hypoleuca. Journal of Avian Biology 35:300-304

Moreno, J.; Morales, J.; Lobato, E.; Merino, S.; Tomás, G. and Martínez-de la Puente, J. 2005. Evidence for the signaling function 
of egg color in the pied flycatcher Ficedula hypoleuca. Behavioral Ecology 16:931-937.

Moreno, J.; Lobato, E.; Morales, J.; Merino, S.; Tomás, G.; Martínezde la Puente, J.; Sanz, J. J.; Mateo, R. and Soler, J. J. 2006. Experimental evidence that egg color indicates female condition at laying in a songbird. Behavioral Ecology 17:651-655.

Narahari, D.; Mujeer, K. A.; Thangavel, A.; Ramamurthy, N.; Viswanathan, S.; Mohan, B.; Muruganandan, B. and Sundararasu, V. 1988. Traits influencing the hatching performance of Japanese quail eggs. British Poultry Science 29:101-112.

Nowaczewski, S.; Witkiewicz, K.; Kontecka, H.; Krystianiak S. and Rosıński A. 2010. Eggs weight of Japanese quail vs. eggs quality after storage time and hatchability results. Archiv Tierzucht 53:720-730.

Obregón, J. F.; Bell, C.; Elenes, I.; Estrada, A.; Portillo J. J. and Ríos F. G. 2012. Effect of discarded chickpea (Cicer arietinum L.) cooking on the productive response and carcass yield of Japanese quail (Coturnix coturnix japonica) at the fattening stage. Cuban Journal of Agricultural Science 46:169-173.

Ojedapo, L. O. and Amao S. R. 2014. Sexual dimorphism on carcass characteristics of Japanese quail (Coturnix coturnix japonica) reared in derived savanna zone of Nigeria. International Journal Science, Environment and Technology 3:250-257.

Omonona, A. O.; Olukole, S. G. and Fayemi, O. O. 2014. Assessment of the developmental anatomy of the Japanese quail (Coturnix japonica) using the gizzard as a growth indicator. PAT 10:12-21.

Samadi, F. and Sahneh, M. 2015. Effects of Artichoke (Cynara scolymus L.) leaf meal and vitamin $\mathrm{E}$ on productive performance: intestinal microflora and morphology in Japanese quail. Poultry Science Journal 3:87-98.

Seker, I.; Kul, S. and Bayraktar, M. 2004. Effects of parental age and hatching egg weight of Japanese quails on hatchability and chick weight. International Journal of Poultry Science 3:259-265.

Siefferman, L.; Navara, K. J. and Hill G. E. 2006. Egg coloration is correlated with female condition in eastern bluebirds (Sialia sialis). Behavioral Ecology and Sociobiology 59:651-656.

Wilkanowska, A.; Kokoszyński D. and Cieślińska J. 2013. Body conformation and morphometry of some internal organs of Pharaoh quail of different ages. Journal of Central European Agriculture 14:358-368.

Yalcın, S.; Akbas, Y.; Otles, S. and Oguz I. 1996. Effect of maternal body weight of quail (Coturnix coturnix japonica) on progeny performance. Ege Üniversitesi Ziraat Fakültesi Dergisi 33:2-3. 